\title{
The Innovation of Augmented Reality Learning Media with Interactive Component Model to Improve Special Ability of Vocational Education Knowledge in the Digital Era
}

\author{
https://doi.org/10.3991/ijim.v15i21.24833 \\ Tuwoso $^{1(\bowtie)}$, Andika Bagus Nur Rahma Putra ${ }^{1}$, Abd Kadir Bin Muhammad ${ }^{2}$ \\ ${ }^{1}$ Universitas Negeri Malang, Malang, Indonesia \\ ${ }^{2}$ Tun Hussein Onn University Malaysia, Johor, Malaysia \\ tuwoso.ft@um.ac.id
}

\begin{abstract}
The development of learning innovation is very rapid, especially in learning media. However, the development of advanced learning media is relatively not widely used. This learning media innovation research aims to: (1) develop learning innovations of augmented reality learning media interactive tractor machine with the 3D model; (2) test the feasibility level of the most recent advances learning media innovation; and (3) test the effectiveness of the most recent advances learning media innovations. The researcher selected to utilize the research and development (R\&D) method for this research and then used a quasi-experimental research method to examine the effectiveness of the development of learning media innovation. Two teams of professionals, e-learning media professionals and vocational education material professionals, work together to validate products. The study's results include the following: First, two teams of validators determined that the augmented reality learning media with interactive 3D produced had a high attraction. Second, in the digital 4.0 era, augmented reality learning media with interactive $3 \mathrm{D}$ produced can help vocational students strengthen their specific abilities.
\end{abstract}

Keywords - augmented reality, interactive models, special abilities, vocational education, digital 4.0

\section{Background}

The development of the world of education continues to experience a substantial evolution. All kinds of learning media began to transform into sophisticated digital media. Various developed countries such as the UK, Germany, France, the United States continue to develop interactive and meaningful learning media [1], [2]. The digital era 4.0 has changed the concept of education so far. In the age of digital literacy, the transformation of electronic learning resources must be the primary emphasis of educational development [3]. However, vocational education to prepare a skilled workforce 
is not yet fully prepared to face this change. The gap is due to the learning media facilities in higher education institutions that cannot keep up with technological developments in the industry. However, currently, the development of sophisticated learning media is relatively challenging to develop. This is due to the limited knowledge and ability of educators to engineering learning media. The digital learning media developed are too monotonous, such as video models, e-modules, and presentation slides. There are not many learning media that are augmented reality or virtual reality models. On the other hand, success in the learning process is influenced by several factors: teachers, students, media, and environmental factors [4], [5].

Changes caused by digitization 4.0 also change the need for work competencies. Job competencies needed in vocational education are usually called special abilities. Even though the education program 4.0 can be aimed at equipping skilled and superior students with the abilities needed by an industry driven by digital technology [5]-[7]. More research and learning materials need to be developed with AR technology and then implemented in the learning process. To develop AR, the necessary technology and 3D models must be prepared, and the appropriate framework must also be considered. Augmented reality has unique abilities that can affect student learning experiences. The development of AR technology allows researchers to develop and evaluate learning experiences using augmented reality [9], [10].

Innovative learning media is a solution that must be used in learning in vocational education. Industrial augmented reality (IAR) is one of the pillars of the concept of industrial digitization [11]. Augmented Reality (AR) learning media are innovative media to solve problems and challenges in education. This technology has the advantage of increasing student interaction and contribution to learning [12]. Augmented Reality (AR) is a digital technology that can display 3D animations of workpieces. Real-world workpieces can be visualized using this digital learning media technology [13]. AR-based digital learning technology benefits can be felt after the availability of resources, lesson planning, and good teacher training [14]. This research aimed to develop augmented reality learning media with $3 \mathrm{D}$ models to help vocational students strengthen their unique abilities in the digital 4.0 era. Industry demands are driving the development of cutting-edge technology-based learning media.

\section{Method}

The researchers used to research and development (R\&D) methodologies to accomplish the research objectives, then used quasi-experimental methods to determine the product's effectiveness. The $\mathrm{R} \& \mathrm{D}$ approach is used to create learning media innovation products, whereas the quasi-experimental approach evaluates learning media innovation effectiveness. The stages that the researcher went through are depicted in detail in Figure 1 below. 


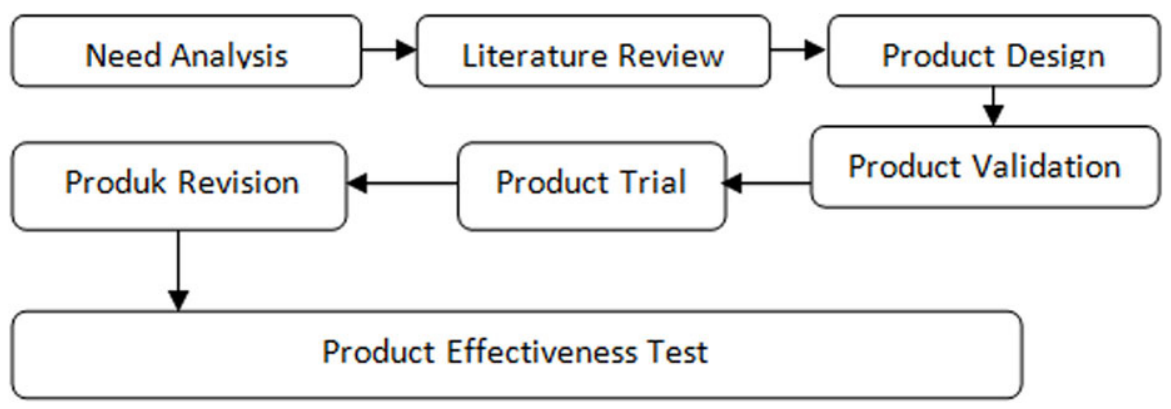

Fig. 1. Development stages scheme

The research stages started from needs analysis, literature study, product design, product validation, product testing, product revision, and product effectiveness testing. Two teams of professionals carried out the validity test. A group of professionals on innovative learning media and professionals on vocational education materials makes up the team. Data collection used expert validation questionnaires and test questionsanalysis of research data using descriptive and inferential statistical analysis techniques.

\section{Result}

Three research findings emerged from the findings of this investigation. This study's findings are divided into three categories: (1) the results of developing innovative learning media based on augmented reality with interactive 3D model innovation, (2) the results of the validation of interactive $3 \mathrm{D}$ models for augmented reality learning media products, and (3) the results of testing the effectiveness of augmented reality learning media with interactive $3 \mathrm{D}$ models learning media.

\subsection{The results of developing innovative learning media based on augmented reality with interactive $3 \mathrm{D}$ model innovation}

The development of this research has resulted in a novel learning media. Figure 2 illustrates the whole presentation of the newly produced learning material. 

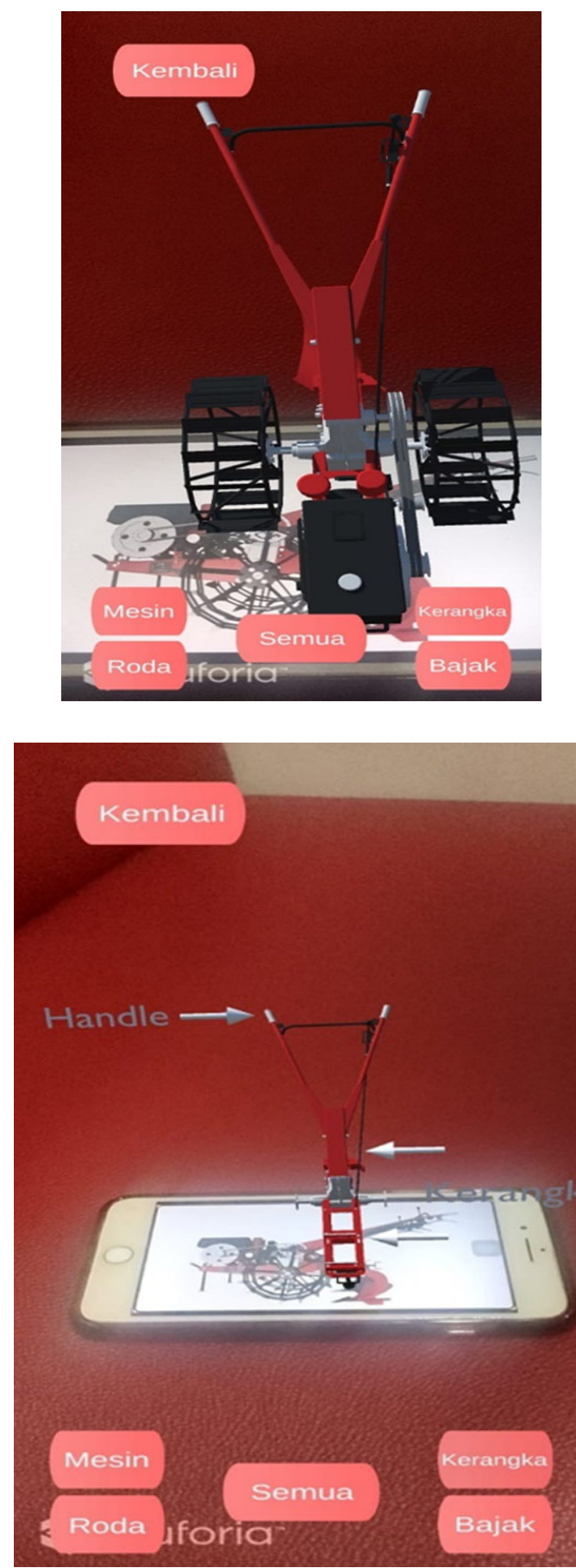

Fig. 2. (Continued) 


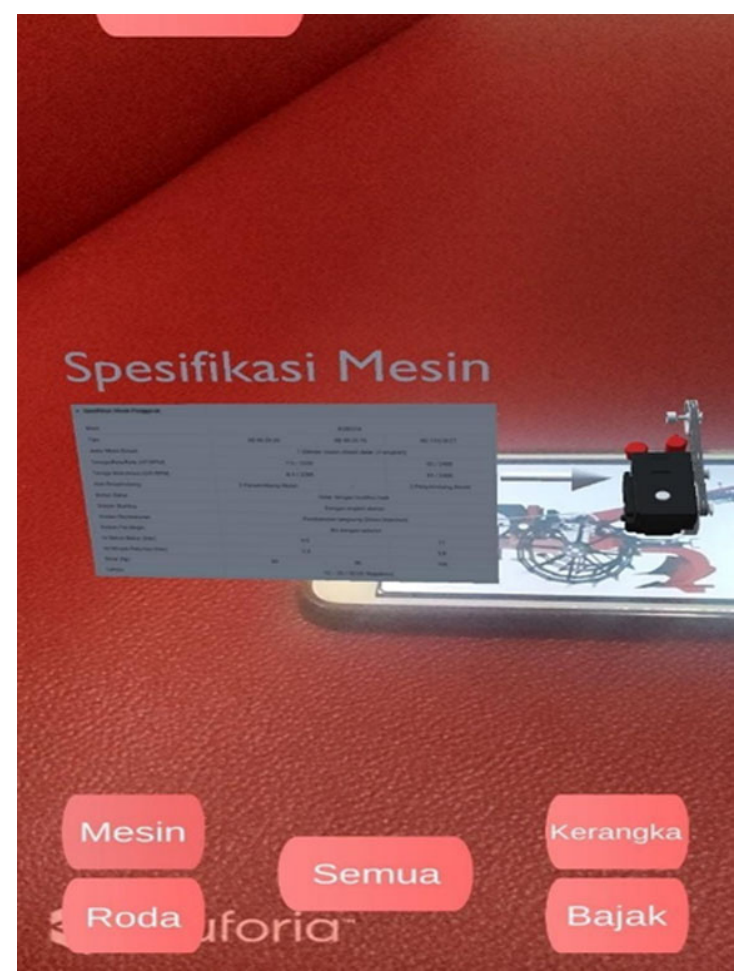

Fig. 2. Display of the developed product homepage

On the augmented reality learning media application site, the interactive tractor machine is an integrated assembly consisting of numerous components, as shown in Figure 2. These components include the engine, wheels, frame, plow, all, and the back button-furthermore, the AR display when the frame and machine buttons the AR application display in camera mode. There are three primary aspects to the display of innovative learning material developed in this study. The first part is an object with a skeleton shape. This section includes the handle and component framework. The second part is the engine specifications. Contains specification is a brief description of the object. The third part is the back button functions to exit camera mode.

\subsection{The results of the validation of interactive 3D models for augmented reality learning media products}

In this study, two teams of product validation experts from universities in vocational education validate the creation of media products. Table 1 shows the complete set of product validation results. 
Table 1. The findings of the descriptive analysis of learning media professionals' validation

\begin{tabular}{|l|l|c|c|}
\hline No. & \multicolumn{1}{|c|}{ Indicator Items } & Score & $\%$ \\
\hline 1 & The level of accessibility of the application & 4.00 & 100.00 \\
\hline 2 & The level of attractiveness of the AR application design & 3.50 & 87.50 \\
\hline 3 & Easy user reading of content and menus & 3.33 & 83.33 \\
\hline 4 & The level of accuracy in selecting colors and 3D models & 4.00 & 100.00 \\
\hline 5 & The toolbar and navigation menu are simple to understand & 3.50 & 87.50 \\
\hline
\end{tabular}

As illustrated in Table 1, there are five indicators of media experts in vocational education validating innovative products. On indicator items one and four, the score obtained is $4.00(100 \%)$. As a result, it can be determined that the creative learning media developed has a high level of validity. Table 2 also shows the process validation by a group of vocational material professionals.

Table 2. Vocational material professionals validation results

\begin{tabular}{|l|l|c|c|}
\hline \multicolumn{1}{|c|}{ No. } & \multicolumn{1}{c|}{ Indicator Items } & Score & \% \\
\hline 1 & The material's compatibility with the competency & 4.00 & 100.00 \\
\hline 2 & The level of originality in the materials on exhibit & 3.33 & 83.33 \\
\hline 3 & The complete presentation of images and videos & 4.00 & 100.00 \\
\hline 4 & The material's appropriate level, as determined & 3.50 & 87.50 \\
\hline 5 & The suitability of the material with the performance & 3.80 & 95.00 \\
\hline
\end{tabular}

As illustrated in Table 2, there are five indicators of the depth of material innovation products based on the validation of vocational materials expertise. On indicator items, one and three get a score of $4.00(100 \%)$. It may be determined that the material quality in the developed vocational learning media has high validity.

\subsection{The results of testing the effectiveness of augmented reality learning media with interactive 3D models learning media}

It was testing the effectiveness of innovative learning media developed using quantitative research methods with quasi-experimental. It was carried out in two classes, namely one control class and one experimental class. The first step is to examine the experimental and control classes' initial abilities, which will be the focus of the study. Table 3 summarizes the findings of the examination of the two classes' initial ability tests.

Table 3. Analysis of the initial ability test results

\begin{tabular}{|c|c|c|c|c|}
\hline \multicolumn{5}{|c|}{ T-test for Equality of Means } \\
\hline T & Df & Sig. & Mean Difference & Std. Error Difference \\
\hline-1.11 & 54 & .2733 & $-1,840$ & 1.6833 \\
-1.11 & 54,358 & .2753 & $-1,840$ & 1.6753 \\
\hline
\end{tabular}


Table 3 depicts the two classes' initial ability tests before adopting augmented reality learning media with 3D models. The summary of these results shows a significance value of 0.2733 . Based on these findings, there is no significant difference in beginning ability between the two classes. According to these findings, there is no significant difference in starting ability between the two classes. In addition, the final ability test results are examined and are presented in Table 4 below.

Table 4. Analysis of the final ability test results

\begin{tabular}{|c|c|c|c|c|}
\hline \multicolumn{5}{|c|}{ T-test for Equality of Means } \\
\hline $\mathbf{T}$ & Df & Sig. & Mean Difference & Std. Error Difference \\
\hline 7,632 & 54 & .004 & 11.9852 & 1.5798 \\
7,602 & 53,167 & .004 & 11.9852 & 1.5758 \\
\hline
\end{tabular}

The analysis results have given the treatment of the experimental class. This uses the latest learning media, and the control class that does not can be seen in Table 4 above. Based on these results, the significant value is 0.004 . This demonstrates that the results of the final ability test of the two classes that are the subject of the study differ significantly. As a result, the most recent learning media items generated in this study are highly effective.

\section{Discussion}

\subsection{The attractiveness of augmented reality learning media with interactive 3D models learning media}

The study's development of augmented reality technology has a high level of appeal. This is supported by the results of two validators in vocational education who are instructional media professionals and material professionals. The validation results show that two indicators of innovative media development get the maximum percentage score, and the results of the validation of vocational materials have two indicators of getting the maximum percentage score. Students' special abilities correlate with the role of learning technology. If the quality of learning technology is good, the student's ability will increase. Cutting-edge learning media simulation is a type of innovative learning technology [15]. The innovative AR learning technology products developed have accessibility, attractiveness, and ease of use. AR technology can transform learning experiences in various disciplines, without exception vocational education [16]. Therefore, an excellent digital learning media development design can optimize the benefits of AR technology. AR learning technology becomes a medium for realizing educational goals. The educational goals to be achieved will be realized by selecting designs that attract users.

This is, of course, in line with AR learning media technology advancement, which aims to meet learning objectives efficiently. The development of an AR learning technology must focus on the suitability of learning materials with target competencies. Accountability for the ethical design of AR product development in a learning environment is essential, especially when integrating media into learning content [17]. The 
target competencies that are focused on in this research are students' unique abilities. One of the unique abilities of students in the digital era 4.0 is the ability to think creatively. The use of AR media can provide a real stimulus for improving student skills. The learning material developed has good novelty. In simple terms, AR can be defined as a natural environment that is added to virtual objects [18], [19]. Merging of real and virtual objects is possible with appropriate display technologies, interactivity is possible through specific input devices, and good integration requires effective tracking. This is the main function of educational media as a source of learning. Educational media can replace the function of educators as learning resources because learning resources consist of messages, people, materials, tools, techniques, and the environment that affect student learning outcomes [20], [21].

\subsection{The effectiveness of augmented reality learning media with interactive 3D models learning media}

As explained above, the development of AR learning media focuses on media and material. This is to ensure that graduates are prepared to meet the unique needs of the industry, which need specialized skills. This learning technology supports student-centered learning. Student-centered learning (SCL) contributes to successful learning [22]. The relevance of AR learning technology realizes the digital era 4.0. Digital transformation is the basis for Industry 4.0 [23], [24]. The increase in students' special abilities can be improved by improving the quality of digital literacy in students. AR learning technology will give lecturers the flexibility to analyze learning problems for students. So that student learning independence can be realized. Good learning must start with the provision of digital technology-based learning media. The demands of the digital era 4.0 cover at least four main abilities that students must have. This competence encompasses mindsets, working, tools, and living in the world skills [25].

This utilization will be able to improve students' unique abilities if appropriately done to realize meaningful learning. AR learning is more effective than video learning for learning with complex motor skills [26]. The advantages of AR learning media are easier to access anywhere, has a high level of attractiveness, and saves more time for student learning. Improving students' unique abilities with digital technology can be optimized with the right pedagogical approach. So that the use of digital learning, apart from being a means of communication and access to information, digital learning technology can be used as an educational or learning tool [27]. Collaborative learning projects have been successfully realized with augmented reality technology [28]. The most recent information distribution method for learning materials is augmented reality (AR). The use of these mediums in teaching aids technical advancement. It is proven that the professional level of students is influenced by the application of AR technology in learning [29].

One of the most straightforward uses of AR in education is to insert it into classroom learning activities. Augmented reality in the classroom can also turn a regular class into something extraordinary for students. We can present examples or simple games made using AR. With interactive visuals, students will more easily absorb the material being taught. $2 \mathrm{D}$ and $3 \mathrm{D}$ objects in AR provide a broader picture to users. Not limited 
to the outside, the user will also see the ins and outs of the object deeper [30], [31]. This certainly creates a different perception to him of something he sees from various perspectives. In the modification phase, the most significant classroom and teaching methods are modified to suit the more specific goals of the technology, thus providing new opportunities for learning that are not available through traditional methods. In the modification stage, the teaching and learning process begins to become more effective.

\section{Conclusion}

The development and testing of the effectiveness of the most recent learning media have a conclusion in three main categories. First, the most recent augmented reality-based learning media technology offers much potential. Second, in the digital era, the latest augmented reality-based learning media technology can help vocational students strengthen their specific abilities. Third, the results of validation by media experts, showed that the item level of accessibility accuracy in selecting images, icons, colors, sounds, and 3D models got the highest score (100\%). The results of the validation by material experts showed that the item material's compatibility with the competency objectives and the complete presentation of images, graphics, and videos on certain materials got the highest score $(100 \%)$. Fourth, the findings of this study can be used as a model for the development of new digital learning technologies with a broader reach and application in the field of education.

\section{References}

[1] A. B. N. R. Putra et al., "The innovation of disruptive learning media with augmented reality based 3D object concept with drill machine design to improve quality of distance learning in the era of education 4.0," Int. J. Interact. Mob. Technol., vol. 15, no. 12, p. 193, 2021. https://doi.org/10.3991/ijim.v15i12.21579

[2] Tuwoso, A. B. N. R. Putra, A. Mukhadis, Purnomo, A. K. Bin Mahamad, and M. S. Subandi, "The technology of augmented reality based on 3D modeling to improve special skills for vocational students in the era of industrial revolution 4.0," J. Phys. Conf. Ser., vol. 1833, no. 1, pp. 1-7, 2021. https://doi.org/10.1088/1742-6596/1833/1/012010

[3] "Digital Revolution of Education 4.0," Int. J. Eng. Adv. Technol., 2019.

[4] S. Papadakis, M. Kalogiannakis, and N. Zaranis, "Teaching mathematics with mobile devices and the Realistic Mathematical Education (RME) approach in kindergarten," Adv. Mob. Learn. Educ. Res., vol. 1, no. 1, pp. 5-18, 2021. https://doi.org/10.25082/ AMLER.2021.01.002

[5] M. Kalogiannakis and S. Papadakis, "Evaluating the effectiveness of a game-based learning approach in modifying students' behavioural outcomes and competence, in an introductory programming course. A case study in Greece," Int. J. Teach. Case Stud., vol. 10, no. 3, pp. 235-250, 2019. https://doi.org/10.1504/IJTCS.2019.10024369

[6] R. Promyoo, S. Alai, and H. El-Mounayri, "Innovative digital manufacturing curriculum for industry 4.0,” Procedia Manufacturing, vol. 34, pp. 1043-1050, 2019. https://doi. org/10.1016/j.promfg.2019.06.092

[7] D. Assante, A. Caforio, M. Flamini, and E. Romano, "Smart education in the context of industry 4.0," 2019. https://doi.org/10.1109/EDUCON.2019.8725057 
[8] "Strengths and Weaknesses of Education 4.0 in the Higher Education Institution," Int. J. Innov. Technol. Explor. Eng., 2019.

[9] I. Martínez-Morales and F. Marhuenda-Fluixá, "Vocational education and training in Spain: steady improvement and increasing value," J. Vocat. Educ. Train., vol. 72, no. 2, pp. 209-227, 2020. https://doi.org/10.1080/13636820.2020.1729840

[10] N. V. Abramovskikh, V. V. Abashina, V. L. Sinebryukhova, V. V. Tolmacheva, and A. R. Filippova, "Experience in designing a system for monitoring and assessing the results of vocational education of a future educator at a university," SHS Web Conf., vol. 101, p. 03022, 2021. https://doi.org/10.1051/shsconf/202110103022

[11] T. Masood and J. Egger, "Adopting augmented reality in the age of industrial digitalisation," Comput. Ind., 2020. https://doi.org/10.1016/j.compind.2019.07.002

[12] M. Sirakaya and D. Alsancak Sirakaya, "Augmented reality in STEM education: a systematic review," Interactive Learning Environments. 2020. https://doi.org/10.1080/10494820.2 $\underline{020.1722713}$

[13] Y. Aoki, S. Ujihara, T. Saito, and Y. Yuminaka, "Development of augmented reality systems displaying three-dimensional dynamic motion in real time," Phys. Educ., 2020. https://doi. org/10.1088/1361-6552/ab9213

[14] J. M. Sáez-López, R. Cózar-Gutiérrez, J. A. González-Calero, and C. J. G. Carrasco, “Augmented reality in higher education: an evaluation program in initial teacher training," Educ. Sci., 2020. https://doi.org/10.3390/educsci10020026

[15] Muchlas, "Developing an online learning media using smartphone for the electrical machinery course," Turkish Online J. Educ. Technol., 2018.

[16] J. Kerr and G. Lawson, "Augmented reality in design education: landscape architecture studies as AR experience," Int. J. Art Des. Educ., 2020. https://doi.org/10.1111/jade.12227

[17] P. Steele, C. Burleigh, M. Kroposki, M. Magabo, and L. Bailey, "Ethical considerations in designing virtual and augmented reality products - virtual and augmented reality design with students in mind: designers' perceptions," J. Educ. Technol. Syst., 2020. https://doi. org/10.1177/0047239520933858

[18] J. Gulikers, D. Brinkman, and P. Runhaar, "Using a rubric to grasp intercultural competence development in vocational education," J. Vocat. Educ. Train., vol. 73, no. 1, pp. 47-70, 2021. https://doi.org/10.1080/13636820.2019.1688854

[19] T. Schmidt, "Teacher as person: the need for an alternative conceptualisation of the 'good' teacher in Australia's Vocational Education And Training sector," J. Vocat. Educ. Train., vol. 73, no. 1, pp. 148-165, 2021. https://doi.org/10.1080/13636820.2019.1698646

[20] M. Kalogiannakis, S. Papadakis, and A. I. Zourmpakis, "Gamification in science education. A systematic review of the literature," Educ. Sci., vol. 11, no. 1, pp. 1-36, 2021. https://doi. org/10.3390/educsci11010022

[21] S. Papadakis, "Advances in Mobile Learning Educational Research (A.M.L.E.R.): mobile learning as an educational reform," Adv. Mob. Learn. Educ. Res., vol. 1, no. 1, pp. 1-4, 2021. https://doi.org/10.25082/AMLER.2021.01.001

[22] T. A. Papp, "A Canadian study of coming full circle to traditional Aboriginal pedagogy: a pedagogy for the 21st century," Diaspora, Indig. Minor. Educ., 2020. https://doi.org/10.108 $0 / 15595692.2019 .1652587$

[23] M. Ghobakhloo, "Industry 4.0, digitization, and opportunities for sustainability," Journal of Cleaner Production. 2020. https://doi.org/10.1016/j.jclepro.2019.119869

[24] A. G. Frank, L. S. Dalenogare, and N. F. Ayala, "Industry 4.0 technologies: implementation patterns in manufacturing companies," Int. J. Prod. Econ., 2019. https://doi.org/10.1016/j. ijpe.2019.01.004 
[25] C. Bergsten and P. Frejd, "Preparing pre-service mathematics teachers for STEM education: an analysis of lesson proposals," ZDM - Math. Educ., 2019. https://doi.org/10.1007/ s11858-019-01071-7

[26] K. E. Chang, J. Zhang, Y. S. Huang, T. C. Liu, and Y. T. Sung, “Applying augmented reality in physical education on motor skills learning," Interact. Learn. Environ., 2020.

[27] T. Karakose, R. Yirci, and S. Papadakis, "Exploring the interrelationship between COVID19 phobia, work - family conflict, family - work conflict, and life satisfaction among school administrators for advancing sustainable management," Sustainability, vol. 13, pp. 1-19, 2021. https://doi.org/10.3390/su13158654

[28] M. Frydenberg and D. Andone, "Enhancing and transforming global learning communities with augmented reality," J. Inf. Syst. Educ., 2018.

[29] A. V. Iatsyshyn et al., "Application of augmented reality technologies for preparation of specialists of new technological era," 2020.

[30] G. K. Randhawa and M. Jackson, "The role of artificial intelligence in learning and professional development for healthcare professionals," Healthc. Manag. Forum, vol. 33, no. 1, pp. 19-24, 2020. https://doi.org/10.1177/0840470419869032

[31] H. Lee, "Artificial intelligence discourse and education planning in cultural content," Int. J. Innov. Creat. Chang., vol. 13, no. 7, pp. 1100-1112, 2020.

\section{$7 \quad$ Authors}

Tuwoso is an associate professor at the University of Malang, Indonesia. He is active in writing journals and books in the field of educational technology. He is active as a resource person and research related to educational technology. The focus of research is on the development of learning technology and innovative learning models.

Andika Bagus Nur Rahma Putra is a productive young lecturer at the Malang State University, Indonesia. He is active in writing scientific papers, researching, and developing learning technology. He also owns more than 100 educational copyrights and often conduct international collaborative research.

Abd Kadir Bin Muhammad is an outstanding lecturer from Tun Hussein Onn University Malaysia, Johor, Malaysia. He conducts research and community service in the field of educational technology. He is active as a resource person and journal reviewer. He often participates in international seminars and collaborates on writing in the field of education.

Article submitted 2021-06-16. Resubmitted 2021-08-09. Final acceptance 2021-08-09. Final version published as submitted by the authors. 